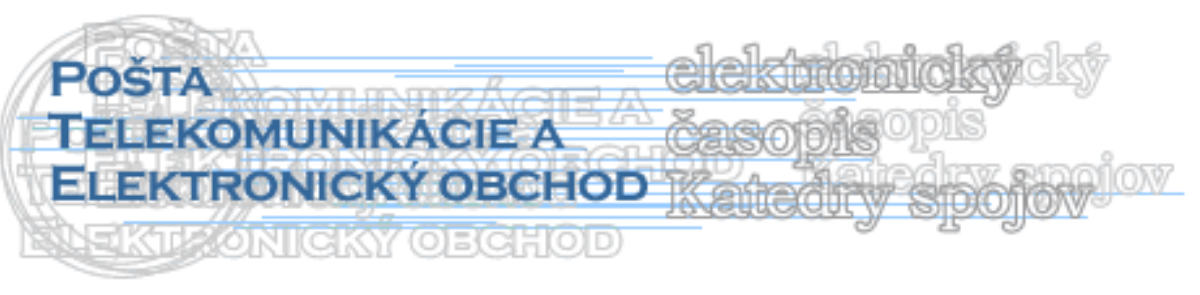

\title{
EURÓPSKY DOŽIVOTNÝ DÔCHODOK
}

\author{
Mária Mičeková, Martina Kováčiková*
}

\section{Úvod}

$\mathrm{Na}$ začiatku 21. storočia, napriek tomu, že Európska únia (EÚ) je jedna z najprosperujúcejších ekonomických oblastí vo svete, rozdiely medzi jednotlivými členskými štátmi sú vel'ké. Inými slovami, nie všetci v rámci Európskej únie majú rovnaké možnosti a príležitosti čelit' výzvam globalizácie. Všetko totiž závisí od skutočnosti, či žijú v prosperujúcom alebo v chudobnejšom regióne; v oblasti, ktorá sa rozvíja, alebo ktorá vplyvom stagnujúceho vývoja upadá; v meste alebo na vidieku; na periférii únie alebo v jej centre.[1]

Ludská populácia starne. Táto skutočnost' predstavuje celosvetový problém, európske krajiny nevynímajúc. V európskych krajinách bude žit' o niekol'ko rokov väčší počet l'udí $\mathrm{v}$ dôchodkovom veku, ako občanov $\mathrm{v}$ produktívnom veku. Reálne sa preto ponúka otázka: ako a z čoho sa budú o niekol'ko rokov vyplácat' dôchodky. Reakcia na túto otázku je aktuálna aj v podmienkach SR.

\section{Dôchodkové zabezpečenie v krajinách EÚ}

Základnou súčast'ou sociálneho modelu každého štátu, ktorý dosiahol určitý stupeň rozvoja, sú systémy dôchodkového zabezpečenia. Dôchodkové zabezpečenie predstavuje systém, ktorý poskytuje $\mathrm{v}$ istom zmysle ochranu obyvatel'om. Ide o sociálny systém, sústred'ujúci obrovský ekonomický potenciál, bez ohl'adu na to či ide o dôchodkový systém finacovaný výlučne priebežne, prevažne priebežne, či kapitalizačne. Financovanie dôchodkového zabezpečenia, tvorí súčast' verejných financií a podstatnou mierou ovplyvňuje ich kvalitu a udržatel'nost'.

Spoločenský, politický a ekonomický vývoj vo svete, vyvolal potrebu reforiem dôchodkových systémov. V štátoch strednej a východnej Európy ovplyvnili reformy hlavne faktory politické a ekonomické. Reformné zmeny dôchodkových systémov prebiehajúce v týchto krajinách, sú obvykle radikálne. V štátoch západnej Európy vznikla potreba reforiem ako reakcia na aktuálny demografický vývoj, prejavujúci sa starnutím populácie. Prebiehajúce reformy predstavujú len čiastočné zmeny. Je možné konštatovat', že v postkomunistických štátoch je reformný proces omnoho dynamickejší a vo väčšine prípadov znamená úplnú zmenu systému, zatial' čo vo vyspelejších štátoch sú prijímané zmeny menej radikálne,

\footnotetext{
* Ing. Mária Mičeková, PhD., Žilinská univerzita v Žiline, F- PEDAS, Katedra spojov Te.: $+421 / 41 / 5133$ 127, fax: $+421 / 41 / 5655615$ e-mail: Maria.Micekova@,fpedas.utc.sk Ing. Martina Kováčiková, PhD., Žilinská univerzita v Žiline, F- PEDAS, Katedra spojov Te.: +421/41/5133 106, fax: +421/41/5655 615 e-mail: Martina.Kovacikova@,fpedas.utc.sk
} 
dlhodobo diskutované a do systému vnášajú čiastočné zmeny, pričom systém si zachováva svoj pôvodný charakter.

Jednoznačným trendom vo vývoji dôchodkových systémov je ich modernizácia. Vyplýva to aj z programu EÚ: „Otvorená metóda koordinácie dôchodkov“, ktorý prijala EÚ v decembri 2001. Program obsahuje spoločné ciele, rozdelené do troch skupín:

\section{1. zabezpečenie primeraných dôchodkov}

- zabránit' sociálnemu vylúčeniu,

- umožnit' občanom zachovanie životnej úrovne,

- podpora solidarity,

2. finančná udržatel'nost' dôchodkového systému

- zvýšenie miery zamestnanosti,

- predíženie pracovného života, zabezpečenie trvalej udržatel'nosti dôchodkových systémov v kontexte silných verejných financií,

- rovnomerne upravit' výšku dávok a príspevkov,

- zabezpečit' primerané a riadne poskytovanie súkromného dôchodkového pripoistenia,

\section{3. modernizácia dôchodkových systémov}

- prispôsobit' sa pružnejším modelom zamestnania a profesijného života,

- podporit' rovnoprávnost' mužov a žien,

- schopnost' dôchodkových systémov reagovat' na nové výzvy.[3]

EÚ teda nestanovuje rovnaký dôchodkový systém pre každý členský štát, ale stanovuje len ciele, ktoré by mali členské krajiny v oblasti dôchodkových systémov splńat'. Napíňanie ciel'ov je zo strany EÚ kontrolované každé dva roky. Členské štáty EÚ majú povinnost', podávat' informácie o svojich dôchodkových systémoch.

Zmeny realizované $\mathrm{v}$ oblasti dôchodkových systémov musia rešpektovat' vyššie uvedené ciele, o.i aj pracovníkov na čiastočný úväzok, dočasne zamestnaných l'udí, samostatne zárobkovo činné osoby, l’udí, ktorí menia prácu, či rovnost' medzi mužmi a ženami.

Dôchodkové systémy v rámci EÚ nie sú harmonizované. Každý členský štát má vlastný dôchodkový systém a teda aj výšku dôchodku vypočítava podl'a vlastných zákonov a dovŕšeného dôchodkového veku, ktorý je v rôznych krajinách rôzny. Najvyšší dôchodkový vek u mužov je v Dánsku - 67 rokov, taktiež u žien je veková hranica odchodu do dôchodku stanovená na 67 rokov. Najnižší dôchodkový vek je u žien a mužov vo Francúzku - 60 rokov. Najväčšie rozdiely odchodu do dôchodku medzi mužom a ženou (65/60) sú v Pol'sku, Rakúsku, Vel'kej Británii, Taliansku.

V prípade cudzincov platí nasledovné: dôchodkové odvody sa platia $\mathrm{v}$ takej výške a štruktúre, ako ich vyžadujú zákony krajiny, v ktorej sa človek zamestná. Zaplatené odvody sa pritom nepresúvajú do krajiny, odkial' pracujúci cudzinec pochádza ale zostávajú v dôchodkovom systéme krajiny, kde tento človek pracuje. Po dovíšení dôchodkového veku, bude občan dostávat' dôchodok $\mathrm{z}$ každej krajiny, kde pracoval a odvádzal dôchodkové odvody.

V rámci tvorby dôchodkových systémov sa môže vo viacerých prípadoch hovorit' o dôchodkových pilieroch, či zdrojoch financovania dôchodku. Dôchodkové systémy sa potom delia podl'a nasledovných kritérií:

- rozsah - dôchodkový systém zahŕňa všetkých občanov alebo len občanov s trvalým pobytom, či skupiny podl'a druhu pracovnej činnosti,

- dobrovol'nost' - povinný alebo nepovinný dôchodkový systém, 
- financovanie - v rámci financovania dôchodku môžeme hovorit’ o financovaní priebežnom alebo kapitálovo rezervnom,

- vzt'ah príspevky a dávky - podl'a tohto kritériá sa rozlišuje dávkovo definovaný systém (DB) alebo príspevkovo definovaný systém (DC),

- zloženie dávok - z tohto pohl'adu sa rozlišuje zloženie dôchodkových dávok jednozložková, dvojzložková dávka, minimálny dôchodok...,

- daňové zvýhodnenie,

- členenie systému z pohl'adu či ide o systém štátny, verejný alebo súkromný.

Ak sa hovorí o dôchodkových pilieroch, obyčajne sa myslí skladba troch dôchodkových pilierov. Vzájomný vzt’ah dôchodkových pilierov môže byt' v jednotlivých krajinách rôzny. Obvykle platí, že prvý pilier je základný a d’alšie dva ho dopíňajú. Podstatné odlišnosti je možné vypozorovat' aj z nasledovných príkladov. Vo Vel'kej Británii je možnost' si zvolit' štátny systém, zamestnanecký alebo individuálny. Trendom v krajinách EÚ je zavádzanie priebežne financovaného, príspevkovo definovaného systému (NDC), ktorý bol vyvinutý vo Švédsku. Tento systém, čiastočne modifikovaný, je uplatňovaný v krajinách napr. Taliansko, Lotyšsko, Pol'sko. [2]

\section{Princípy vyplácania dôchodkov v zahraničí}

Jednou z najdôležitejších dávok sociálneho zabezpečenia je výplata starobného dôchodku. V prípade, že osoba vykonáva profesijnú činnost' len v jednom štáte, výplata starobného dôchodku je jednoduchšia a podlieha princípom výplaty starobného dôchodku príslušnej krajiny (teda jednej). Ak však človek plánuje vykonávat' svoju profesijnú činnost' vo viacerých štátoch EÚ, je potom dôležité , aby získal predstavu o budúcom práve na starobný dôchodok, ktorý sa bude skladat' z viacerých častí, v závislosti od počtu krajín v ktorých vykonával profesionálnu pracovnú činnost'.

V rámci EÚ sú uplatňované určité princípy, vzt’ahujúce sa na osoby, ktoré prestali pracovat' $v$ jednej krajine a začali pracovat', resp. pokračovat' vo svojich aktivitách $v$ inej krajine. Princípy vyplácania takýchto typov dôchodkov sú nasledovné:

- neprevoditel'nost' na inú krajinu - v každej krajine, v ktorej bola osoba poistená, sa uchováva záznam príspevkov, pokým nedosiahne dôchodkový vek, tzn. že príspevky, ktoré sa platia nebudú prevádzané do inej krajiny a ani sa oprávnenej osobe nevyplatia, ak už nie je v príslušnej krajine poistená,

- vyplácanie starobného dôchodku - v prípade, že bola osoba poistená v krajine viac ako jeden rok, bude musiet' príslušná krajina vyplácat' oprávnenej osobe starobný dôchodok, ked' táto osoba dosiahne dôchodkový vek, tzn. ak oprávnená osoba pracovala v troch krajinách (viac ako rok, platila poistné), budú jej vyplácané tri samostatne oddelené starobné dôchodky,

- výpočet výšky starobného dôchodku - dôchodok sa oprávnenej osobe vypočíta na základe jej záznamov o platení príspevkov v príslušnej krajine, tzn. ak tam bola osoba poistená počas dlhej doby, dostane relatívne vysoký dôchodok, v prípade, že osoba bola poistená kratšie časové období, jej dôchodok bude relatívne nízky.

Uvedené princípy vzt'ahujúce sa na výplatu dôchodkov, sú zárukou toho, že žiadna osoba nebude znevýhodnená tým, že pracovala vo viacerých krajinách. Príspevky oprávnených osôb neprepadnú a je zabezpečené rešpektovanie nadobudnutých práv na 
výplatu starobných dôchodkov, tzn., že každá krajina zaplatí dôchodok prislúchajúcim dobám platenia príspevkov získaných $\mathrm{v}$ predmetnej krajine. Výsledok je prospešným pre všetky členské krajiny, pretože ani jedna z krajín neplatí viac, či menej ako dôchodok, na ktorom sa oprávnená osoba svojimi príspevkami podiel'ala.

Zvláštny prípad môže nastat' v prípade (napr. Slovenská republika), že občan pracuje mimo územia svojej krajiny len krátky časový úsek a vie, že sa chce vrátit' a d'alej pracovat' vo svojej domácej krajine. V takom prípade môže dobrovol'ne platit' odvody v domácej krajine a to ako tzv. dobrovol'ne poistená osoba. Obdobie platby dobrovol'ného poistenia sa započítava do starobného dôchodku a prejaví sa aj na jeho budúcej výške.

Z vyššie uvedeného textu, je možné formulovat' všeobecné pravidlá uplatňujúce sa pri vyplácaní dôchodkov osôb pracujúcich v zahraničí:

- požadované podmienky, úhrn dôb - ak doba, v ktorej bola osoba poistená v jednej krajine, nie je dostatočne dlhá na to, aby mala oprávnená osoba nárok na dôchodok v príslušnej krajine, zohl'adní sa l'ubovol'ná doba platenia príspevkov splnená $\mathrm{v}$ ostatných krajinách

- bydlisko alebo pobyt v zahraničí - starobný dôchodok sa bude osobe vyplácat' bez ohl'adu na to, kde bývala, alebo kde má trvalý pobyt v rámci EÚ či EH priestoru, bez zníženia modifikácie alebo pozastavenia. Toto sa uplatňuje nielen na bývalých „migrujúcich pracovníkov“, ale aj na všetkých dôchodcov $\mathrm{s}$ bydliskom $\mathrm{v}$ inom štáte.

Tento princíp nemožno uplatňovat' na niektoré špeciálne nepríspevkové dávky, ktoré sa vo väčšine prípadov získavajú po zistení ekonomických príjmov žiadatel'a, tzn. patria osobám, ktoré dostávajú dôchodok nižší, ako je určitá minimálna hranica. Ide napr. o príjmy garantované osobám v pokročilom veku v Belgicku, dodatočná dávka Národného fondu solidarity vo Francúzsku a iné.

Problémy, ktoré môžu nastat' v súvislosti s problematikou vyplácania dôchodkov v zahraničí, sa prevažne týkajú:

- rozdielneho dôchodkového veku,

- menových kurzov,

- poštových a bankových poplatkov. [2]

\section{Záver}

$\mathrm{Na}$ záver je možne konštatovat', že všetci pracujúci v danom členskom štáte majú právo na rovnakú ochranu, nevynímajúc dôchodkové zabezpečenie v starobe a pri ovdovení. Európske právo však neupravuje predčasné odchody do dôchodku ani otázky dodatočného dôchodkového poistenia. Občan EÚ má právo na výplatu dôchodku n území vlastnej krajiny ale v oprávnenom prípade aj na území ktoréhokol'vek členského štátu.

Ako úspešne dokážu aktuálne realizované dôchodkové reformy, zabezpečit' zdroje financovania budúcich dôchodkov, budeme môct' konštatovat' až o niekol'ko rokov. 


\section{Literatúra}

[1] JANKALOVÁ, M.: Rozvoj regiónov formou budovania podnikatel'skej infraštruktúry. In: Medzinárodná vedecká konferencia ROZWÓJ EUROREGIONU BESKIDY II Doświadczenia - oczekiwania - perspektywy. Zeszyty naukowe Wyzszej szkoly bankowości i finansów w Bielsku-Bialej, NR 3. Žilina: 27. február 2003. Bielsko-Biala: WSBiF 2003, s. 76-83. ISSN 1429-673X.

[2] MIČEKOVÁ, M., ČUBOŇOVÁ, J.: Európsky doživotný dôchodok a jeho aplikácia na podmienky SR, Diplomová práca, Žilinská univerzita v Žiline, 2007

[3] http://www.euroinfo.gov.sk

[4] http://www.openiazoch.sk

[5] http://dochodok.gov.sk

[6] http://ns-sk.ca

\section{Grantová podpora}

MVTS NEM/ SR/ ŽU 2 / 07 - Zákaznícka spokojnost' v bankovom sektore 